A N N A L E S

UNIVERSITATIS MARIAE CURIE-SKŁODOWSKA

LUBLIN - POLONIA

VOL. LXVI, 2

SECTIO G

2019

Politechnika Rzeszowska

MARCIN MERKWA

mmerkwa@prz.edu.pl

ORCID: 0000-0001-7288-4552

\title{
Francisca de Vitorii uzasadnienie kolonizacji Ameryki z perspektywy rozwoju idei praw naturalnych
}

Francisco de Vitoria's Justification for the Colonization of America.

Natural Rights' Perspective

\section{WPROWADZENIE}

Truizmem jest stwierdzenie, iż odkrycie Nowego Świata doprowadziło do zmian na Starym Kontynencie, których znaczenie trudno przecenić. Jednakże warto pamiętać, że nie tylko gospodarkę czy politykę ukształtowały wydarzenia z końca XV i początku XVI w. Odkrycie Ameryki wpłynęło również na rozwój niektórych idei, w tym na koncepcję uprawnień naturalnych jednostki. Wydarzenie to postawiło przed myślicielami Starego Kontynentu pytania, które wpisały się na trwałe w intelektualną tradycję Europy. Trzy wielkie powroty przyniesione przez nowe prądy epoki (powrót do autorytetów antyku, do Biblii w dobie Reformacji i wreszcie do autorytetu św. Tomasza w okresie drugiej scholastyki) ukształtowały postrzeganie człowieka, jego relacji z Bogiem, władzy i społeczeństwa. Żaden z tych powrotów nie stanowił jednak prostego powtórzenia przeszłych idei - bardzo często było to bowiem przetworzenie i - co chyba najważniejsze zaadaptowanie określonych koncepcji do nowych warunków społeczno-ekonomicznych. Znaczenie myślicieli tego okresu (w tym przedstawicieli hiszpańskiej scholastyki) wynika w dużej mierze z tego, że próbowali zmierzyć się z nowymi zagadnieniami, lecz również (a może przede wszystkim) z tego, iż w tym procesie wykorzystywali narzędzia pozostawione przez poprzedników.

Ze względu na rolę Hiszpanów w eksplorowaniu Nowego Świata to właśnie uczeni z tego kraju znaleźli się w awangardzie debat filozoficzno-prawnych i byli odpowiedzialni za największe dokonania w scholastycznej myśli od czasów 
Tomasza z Akwinu' ${ }^{1}$ Wiek XVI to czas rozkwitu filozofii tomistycznej zarówno w Hiszpanii, jak i w innych krajach. W owym czasie hiszpańscy myśliciele, szczególnie ci skupieni w Szkole z Salamanki, rozwijali głównie tomistyczną filozofię moralną i polityczną. $Z$ tego powodu problematyka uprawnień naturalnych była analizowana w znacznej mierze przez pryzmat spuścizny Arystotelesa i św. Tomasza, lecz można dostrzec też wpływy Augustyna, Dunsa Szkota czy myślicieli XV i XVI w., w tym Tommaso de Vio, którego idee dotyczące podstaw funkcjonowania społeczeństwa odcisnęły piętno na myślicielach Szkoły. Tommaso de Vio argumentował, iż wszyscy ludzie posiadają prawo (ius), umocowane w prawie naturalnym, zarówno do wybrania formy rządów, jak i tych, którzy władzę będą sprawować. Wśród innych myślicieli XVI w., którzy kształtowali moralne i polityczne nauczanie scholastyki hiszpańskiej, można wskazać Alonzo de Castrilo, który w Tractado de Republica z 1521 r. pisał, iż mężczyźni i kobiety zostali stworzeni jako samotne byty, które stają się społeczne dzięki otrzymanemu od Boga rozumowi - społeczna natura człowieka związana jest więc z jego racjonalnością. Podtrzymując Augustiańską tezę, zgodnie z którą państwo jest konsekwencją grzesznej natury człowieka po upadku, myśliciel - podobnie jak wielu mu współczesnych - postrzegał powstanie społeczeństw jako samodzielną decyzję ludzi, naznaczoną jednak boskim nakazem ${ }^{2}$.

Spuścizna Szkoły, będąca punktem wyjścia wielu debat drugiej połowy XVI oraz XVII stulecia, budzi szereg wątpliwości. Choć jądro politycznej doktryny Szkoły jest dobrze znane jako część intelektualnego dziedzictwa Europy, to:

[...] wciąż toczy się debata dotycząca ich filozofii prawa - ich filozofii uprawnień (rights) oraz wywiedzionych z niej aspektów politycznej filozofii. Uogólniając, spór toczy się pomiędzy tymi, którzy utrzymują, że Szkoła reprezentuje powrót do autentycznej tomistyczno-arystotelesowskiej myśli, w której prawo naturalne i uprawnienia postrzegane są jako przedmiot sprawiedliwości (,uprawnienia obiektywne”), a tymi, którzy argumentują, że pomimo iż pozornie hiszpańscy neotomiści byli wierni Arystotelesowi i Akwinacie, to w rzeczywistości postrzegali uprawnienia jako władztwo bądź wolność jednostki („uprawnienia subiektywne”), a więc ich polityczna teoria bazuje na takim postrzeganiu uprawnień i stanowi zapowiedź teorii Hobbesa ${ }^{3}$.

Doktryna uprawnień naturalnych, której podwaliny kształtują się w późnośredniowiecznej Europie przede wszystkim w ramach sporów o ubóstwo, a która przygotowała grunt pod nowożytne koncepcje takich myślicieli, jak Grocjusz,

1 L. Henke, Bartolomé de las Casas: An Interpretation of His Life and Writings, The Hague 1951, s. 38.

2 M.W.F. Stone, The Nature and Significance of Law in Early Modern Scholasticism, [w:] A Treatise of Legal Philosophy and General Jurisprudence, Vol. 6: A History of the Philosophy of Law from the Ancient Greeks to the Scholastics, ed. F.D. Miller, Dordrecht 2007, s. 337-338.

3 A.S. Brett, Liberty, Right and Nature. Individual Rights in Later Scholastic Thought, New York 2003, s. 1. 
Hobbes czy Locke, była w owym czasie nie tylko ważną częścią teorii hiszpańskich myślicieli, ale również - jak chcą niektórzy badacze - to właśnie dzięki nim mogła wejść w nowożytną kulturę europejską:

Cała doktryna uprawnień naturalnych - sprowadzona do pewnego rodzaju scholastycznej gry słownej, odległa od życia codziennego - mogłaby zostać zmieciona w nowym świecie renesansowego humanizmu. [...] Jednakże nowe nieprzewidziane wydarzenie zmieniło wszystko - odkrycie przez Europejczyków Ameryki. Nagle abstrakcyjny scholastyczny dyskurs stał się istotny dla historycznych problemów nowego wspaniałego świata, możliwego uzasadnienia kolonializmu, prawa ludności tubylczej. Hiszpania była miejscem narodzin wielkiej debaty, która często koncentrowała się ponownie na koncepcie uprawnień naturalnych. Czy prawa te mogą być rzeczywiście prawami uniwersalnymi? Czy niektórzy ludzie są z natury niewolnikami, jak chciał Arystoteles? Czy prawa są przynależne nie tylko cywilizowanym ludziom, takim jak Hiszpanie, ale i bałwochwalcom, kanibalom, nagim dzikusom? ${ }^{4}$

Podobnie rzecz się ma z analizą spuścizny Vitorii. Nawet w katolickiej doktrynie neotomistycznej nie było zgody w kwestii oceny jego dorobku - jedni badacze uznali, że Vitoria nigdy nie używał terminu ius dla mówienia o prawach podmiotowych, podczas gdy np. Villey pisał, że Vitoria ,zdradził” nauczanie Akwinaty, przyznając prawa o charakterze subiektywnym (subjective rights) amerykańskim Indianom. Współczesna akceptacja praw człowieka przez Kościół katolicki wpływa na argumentację niektórych badaczy, którzy piszą o wierności, jaką miał wykazać Vitoria poglądom św. Tomasza, kiedy rozwijał nakreślone przez Akwinatę fundamenty teorii uprawnień. Jednakże Akwinata nigdy nie nauczał o uprawnieniach naturalnych, nie przedstawił również jednej definicji ius ${ }^{5}$. Niezależnie od wyżej wskazanego sporu należy stwierdzić, że doktryna Vitorii była zakorzeniona w wielu różnych ideach, debatach i poglądach wcześniejszych myślicieli; na kształtowanie się jego doktryny wpływ miały argumenty podnoszone przez Ockhama i nauczanie Akwinaty o sprawiedliwości, ale też doktryna Gersona o uprawnieniach, przekazana przez Summenharta.

\section{UPRAWNIENIA NATURALNE VITORII}

W kluczowym dla analizy koncepcji uprawnień naturalnych tekście, jakim jest De Indis ${ }^{6}$, pada pytanie: Czy Indianie przed przybyciem Hiszpanów byli ,prawdziwymi, w zakresie uprawnień publiczno- i prywatnoprawnych, to znaczy czy byli oni prawdziwymi właścicielami swego prywatnego majątku i posiadłości, i czy byli

4 B. Tierney, The Idea of Natural Rights - Origins and Persistence, "Northwestern Journal of International Human Rights" 2004, Vol. 2(1), s. 10.

5 Idem, The Idea of Natural Rights: Studies on Natural Rights, Natural Law, and Church Law 1150-1625, Cambridge 2001, s. 258.

6 F. de Vitoria, On the American Indians (De Inidis), [w:] Vitoria: Political Writings, eds. A. Pagden, J. Lawrence, Cambridge 1991 (wydanie polskie: O Indianach, Warszawa 1954). 
wśród nich prawdziwi przywódcy i zwierzchnicy?’7 Vitoria uznaje, że można argumentować, iż bez wątpliwości Indianie byli posiadaczami swych dóbr przed przybyciem Hiszpanów, więc muszą być traktowani jako właściciele, chyba że można będzie wykazać coś innego i nie mogą być pozbawieni posiadania bez wykazania stosownej podstawy prawnej. ${ }^{8}$. Według Vitorii istnieją tylko cztery powody wykluczające możliwość posiadania przez Indian dominium: mogli być oni grzesznikami, poganami, ludźmi o słabym umyśle lub pozbawionymi rozumu9

Stanowisko Vitorii, zgodnie z którym Indianie nie mogą być pozbawieni naturalnego dominium, nawet jeśli zostaną uznani za grzeszników, było zgodne z wówczas dominującym poglądem - dominium przynależy człowiekowi, gdyż jest on istotą stworzoną na podobieństwo Boga i nie zostało ono utracone przez grzech. Pisze Vitoria:

[...] a w ogóle jest to [twierdzenie, iż zdolność do bycia właścicielem zostaje utracona w stanie grzechu śmiertelnego - M.M.] oczywista herezja. Podobnie jak Bóg każe jednakowo wschodzić słońcu nad dobrymi i złymi ludźmi i jak spuszcza deszcz na sprawiedliwych i na niesprawiedliwych, tak dał dobra doczesne zarówno dobrym, jak i złym ${ }^{10}$.

Podobnie rzecz się ma z grzechem niewiary. Po przedstawieniu argumentów na rzecz tezy, zgodnie z którą poganin nie może być właścicielem, Vitoria odrzuca je, twierdząc, iż „Indianom nie można zaprzeczyć prawa własności z punktu widzenia tak publiczno-, jak i prywatnoprawnego ani ze względu na grzech niewiary, ani inne grzechy śmiertelne: na tej podstawie nie mogą zagarniać ich dóbr i ziem [...]"11. W dalszej części De Indis dominikanin rozpatruje sytuację dzieci zanim osiągną wiek, w którym „zaczną posługiwać się rozumem”. Dziecko, choć niezdolne do posługiwania się rozumem, może doznać krzywdy, ma więc prawo do rzeczy i może być właścicielem; ponadto „podstawą własności jest to, aby ktoś stworzony był na obraz Boga" - pisze Vitoria, a dzieci cechę tę posiadają ${ }^{12}$. Jeśli zaś idzie o osoby trwale pozbawione zdolności kierowania swoim postępowaniem za pomocą rozumu, to według Vitorii wydaje się, że mogą być one właścicielami, gdyż również mogą doświadczyć krzywdy (Vitoria nie wypowiada się tu z całkowitą pewnością i pozostawia tę kwestię do rozstrzygnięcia prawnikom $)^{13}$.

7 Ibidem, 1,4. Warto zauważyć, że problematyka związana z odkryciami Nowego Świata pojawia się również w innych tekstach, np. w De potestate ciuil, gdzie Vitoria krótko uzasadnia, że niechrześcijanie mogą mieć prawowitych władców. Zob. idem, On Civil Power, eds. A. Pagden, J. Lawrence, Cambridge 2012, 1,6.

$8 \quad$ Idem, De Indis, 1,5.

9 B. Tierney, The Idea of Natural Rights: Studies..., s. 266.

${ }_{10}$ F. de Vitoria, De Indis, 1,6.

11 Ibidem, 1,19.

12 Ibidem, 1,21.

13 Ibidem, 1,22. 
Wydawać się może, że przytaczanie takich fragmentów obrazuje jedynie meandry scholastycznej argumentacji. Jednakże w literaturze przedmiotu zwraca się uwagę, iż Vitoria w swoim dziele wyraża zasadę, która stanie się fundamentem wielu przyszłych teorii niezbywalnych praw jednostki, które za centralną kategorię praw człowieka i ich źródło będą uznawać jednostkę ludzką ${ }^{14}$. Vitoria rozwija tę tezę, odwołując się do doktryny Tomasza, który pisał, iż tylko istota rozumna posiada władzę nad swoimi czynami - dla Akwinaty kluczowa dla rozróżnienia między istotą ludzką a pozostałym ziemskim stworzeniem była przynależna ludziom możliwość podejmowania swobodnych decyzji. Komentując Tomasza, Vitoria pisał, że ,zwierzęta nie posiadają praw, ale ludzie tak (habet ius)"15.

Status Indian Vitoria określił następująco:

Indianom nie można odmówić prawdziwej własności z powodu tej ostatniej przyczyny [bezrozumności - M.M.]. Teza ta znajduje swe poparcie w fakcie, że dzicy w istocie rzeczy nie są pozbawieni rozumu, lecz używają go na swój sposób. Jest to rzeczą niewątpliwą, ponieważ zachowują pewien porządek w swych poczynaniach, skoro mają państwo oparte na pewnej organizacji, zawierają małżeństwa w określonej formie, mają urzędników, przywódców, prawa, rzemiosło, obrót handlowy - a wszystko to są sprawy wymagające używania rozumu ${ }^{16}$.

Vitoria odrzucił twierdzenie, zgodnie z którym Indianie nie byli „,prawdziwymi właścicielami z punktu widzenia prawa publicznego i prywatnego”. Większość argumentów na rzecz tego stanowiska opierała się na uznaniu Indian za niewolników z natury ze względu na brak rozumu pozwalającego na kierowanie swoim postępowaniem. Vitoria jednak dokonuje rozróżnienia na zniewolenie wynikłe z natury i oparte na prawie państwowym. Warto zauważyć, że interpretacja poglądów Arystotelesa dokonywana przez Vitorię nie zawsze wydaje się przekonująca. Filozof prawdopodobnie nie zgodziłby się z następującym twierdzeniem: „Arystoteles z pewnością nie był tego zdania, jakoby ci, którzy z natury są słabo rozwinięci umysłowo, mieli podlegać cudzej władzy i nie posiadać sami władzy nad sobą ani prawa własności" ${ }^{\prime 1}$.

Charakteryzując dorobek Vitorii, Robert J. Araujo pisze o trzech konkluzjach, do których doszedł Franciszek. Po pierwsze, Vitoria uznał, że Indianie spotkani przez Hiszpanów w Nowym Świecie to racjonalne istoty ludzkie, zdolne do samostanowienia, a więc mogące być np. właścicielami. Po drugie, uznał powszechność praw. Po trzecie zaś, określił relacje pomiędzy tubylcami i obcymi ${ }^{18}$. Koncepcja Vitorii została oparta o charakterystyczną antropologię filozoficzną:

14 B. Tierney, The Idea of Natural Rights: Studies..., s. 268.

15 Cyt. za: ibidem.

16 F. de Vitoria, De Indis, 1,23.

17 Ibidem, 1,24.

18 R.J. Araujo, The Catholic Neo-Scholastic Contribution to Human Rights: The Natural Law Foundation, “Ave Maria Law Review” 2003, Vol. 159, s. 165 i n. 
dzięki stałości natury ludzkiej prawa przysługujące ludziom, ale i ciążące na nich obowiązki, są takie same - ,jedną z fundamentalnych cech praw przysługujących istotom ludzkim jest więc równość. Każda istota ludzka ma prawo tak do moralnej godności, jak i do tego, co konieczne, by ją zagwarantować, ponieważ jest człowiekiem"'19.

\section{DOKTRYNA UPRAWNIEŃ NATURALNYCH A UZASADNIENIE OBECNOŚCI HISZPANÓW W NOWYM ŚWIECIE}

Doktryna praw naturalnych została wykorzystana przez Vitorię nie tylko do wykazania podmiotowości Indian, ale także do uzasadnienia obecności Hiszpanów w Nowym Świecie. Możliwość dostania się Indian pod władze Hiszpanów może być według tego myśliciela wykazana na kilka sposobów. Otóż może wynikać z naturalnych stosunków panujących w społeczności ludzkiej. Dowodów na rzecz tej tezy Vitoria dostarczył wiele, rozpoczynając od problematyki ius gentium, które wymaga m.in. życzliwości $\mathrm{w}$ relacjach $\mathrm{z}$ cudzoziemcami ${ }^{20}$. Vitoria w pewnym zakresie przeciwstawia prawo naturalne prawu narodów - ius gentium nie określa, co jest z natury sprawiedliwe, lecz jedynie stwierdza, co powinno być robione, aby osiągnąć cel z natury słuszny. Takie rozróżnienie nakazuje uznać, że ,ius gentium jest raczej zawarte w prawie pozytywnym, a nie w naturalnym" 21 . Oczywiście użycie w przytoczonym zdaniu partykuły „raczej” czyni stwierdzenie mniej przekonującym i sugeruje wątpliwości Vitorii co do statusu ius gentium. Pamiętać należy, że Vitoria musiał zmierzyć się z długą tradycją dotyczącą omawianej materii. Średniowieczni juryści w zakres ius gentium włączyli wszystko, co wspólne ludziom - takie ujęcie stanowiło spuściznę po rzymskim pojmowaniu ius gentium. Jednakże Vitoria pojmuje omawiane prawo jako nakaz wiążący suwerenne państwa, którego źródeł należy szukać m.in. w fakcie, że ludzkość jest podzielona na wiele wspólnot politycznych. Cała polityczna teoria Vitorii była zbudowana na założeniu o suwerenności i niezależności tych wspólnot, przy czym podział ludzi na określone grupy nie wynikał z nakazów prawa naturalnego, lecz stanowił wyraz decyzji, jakie podjęli oni w przeszłości (niezależność i równorzędność wszystkich wspólnot implikowała przypisanie tych cech tak królestwom chrześcijańskim, jak i państwu Indian). Jeśli istnienie poszczególnych państw nie wynika z nakazów prawa natury, to ius gentium nie może być elementem tego prawa. Nie oznacza to, że nie istnieją związki pomiędzy prawem narodów i prawem naturalnym (prawo naturalne zawiera trzy rodzaje zasad: a) powszechnie znane i oczywiste, b) wynikające z nich konieczne wnioski i c) ich moralne konsekwen-

19 M.W.F. Stone, op. cit., s. 341.

20 F. de Vitoria, De Indis, 3,2.

21 Cyt. za: C.G. Norena, Studies in Spanish Renaissance Thought, The Hague 1975, s. 140. 
cje, które są wysoce prawdopodobne). Ius gentium nie może w sposób konieczny wynikać z prawa naturalnego (bo byłoby wtedy prawem naturalnym), wynika więc zdaniem Vitorii w sposób „prawie konieczny”22.

Vitoria akceptuje to, co później zostanie przyjęte przez szkoły racjonalistyczne, a więc uznanie ius gentium za wynik działalności ludzkiego rozumu. W trzeciej części De Indis pisze: „,...] prawo narodów (ius gentium), które bądź to jest prawem naturalnym, bądź też wywodzi się z prawa naturalnego: »Prawem narodów nazywamy takie prawo, które ustanowił między wszystkimi ludźmi wrodzony rozsądek « (Inst. I, 2,1)”23. Jak zauważa Vitoria, prawo narodów może przyjąć różną postać: może być sformalizowane, powszechne (znajdujemy je w kompilacjach prawniczych i takich zbiorach, jak Instytucje) lub może mieć charakter partykularny (prawo o takim charakterze tworzone jest przez państwa na mocy umów zawieranych między nimi). Prawo narodów w pierwszej postaci powstaje na podstawie zgody większości (umawiające się strony to państwa, a nie poszczególne jednostki ludzkie) i, co istotne, wiąże również mniejszość, która nie wyraziła zgody na przyjęcie zasad. Ostatecznym celem ius gentium jest powszechne dobro rodzaju ludzkiego, podobnie jak celem prawa pozytywnego poszczególnych społeczeństw jest dobro państwa. Tym dobrem jest według Vitorii pokój i zgoda między ludźmi ${ }^{24}$.

Oprócz ius gentium na rzecz istnienia określonych naturalnych stosunków Vitoria wskazuje m.in.:

a) wolność podróżowania istniejącą od zarania świata, której nie przekreśliło powstanie własności prywatnej,

b) wolność czynienia wszystkiego, co nie jest zakazane i co nie przynosi krzywdy innym ludziom (tu Vitoria zakłada, że takie właśnie są podboje Hiszpanów),

c) jako że wygnanie jest jedną z kar głównych, nie można usuwać przybyszów, jeśli nie można im przypisać winy,

d) nie można stosować wygnania, nie prowadziwszy wojny sprawiedliwej (a takiej według Vitorii Indianie nie prowadzili z Hiszpanami),

e) przyjaźń i towarzystwo innych ludzi wynikają wprost z prawa naturalnego,

f) jeśli prawo ludzkie zabraniałoby bez uzasadnienia w prawie naturalnym wstępu Hiszpanom, to nie miałoby ono mocy prawnej jako sprzeczne z godnością ludzką i rozumem,

22 Ibidem, s. 141.

23 F. de Vitoria, De Indis, 3,2. Wydaje się, że słowa Vitorii zacytowane w tym miejscu nie przeczą wcześniejszym twierdzeniom dotyczącym rozdziału ius gentium od prawa naturalnego. Vitoria na początku trzeciej części De Indis rozważa m.in. prawo Hiszpanów do wypraw do Nowego Świata i, nie chcąc roztrząsać w tym miejscu pozycji prawa narodów, wykazuje, że naruszenie ius gentium musi być uznane za grzech, niezależnie od uznania go za część czy to ludzkiego, czy to naturalnego porządku.

24 C.G. Norena, op. cit., s. 144. 
g) nakaz miłości bliźniego z Ewangelii wiąże również Indian,

h) „[... albo Hiszpanie są poddanymi Indian, albo nie. Jeśli nie są - to Indianie nie mają prawa zabraniać im wstępu do siebie, jeśli zaś są - to powinni się do nich odnosić z życzliwością"25.

Wykazanie, że naturalną rzeczą jest powstawanie określonych relacji między Hiszpanami a Indianami pozwala Vitorii przyjąć za naturalne istnienie relacji handlowych. Teza ta wynika zarówno z pierwszej, już udowodnionej tezy, jak i znajduje samodzielne uzasadnienie w prawie narodów oraz prawie boskim. Wyjątkowo ważne jest przyjęcie, że Indianom nie przysługuje więcej praw niż innym narodom. Odwołując się do Digestów, zauważa, że z natury wynikają więzi pokrewieństwa pomiędzy wszystkimi ludźmi. Kluczem jest więc uznanie Indian za pełnoprawnych członków społeczności ludzkiej. W dalszej części tekstu Vitoria wykazuje jeszcze między innymi, iż Hiszpanie powinni mieć prawo do korzystania z rzeczy wspólnych - urodzonym na ziemi indiańskiej dzieciom hiszpańskim powinny przysługiwać wszystkie prawa, a także sposób postępowania w przypadku, gdyby Indianie odmawiali należnych Hiszpanom praw. W podobny sposób Vitoria dowodzi również prawa Hiszpanów do korzystania z rzeczy stanowiących wspólną własność Indian i cudzoziemców (np. złoto) czy prawa hiszpańskich dzieci do nabycia indiańskich ,praw obywatelskich”26.

Warto odnotować, że oprócz ukazania, do czego uprawnieni są przybywający do Nowego Świata Hiszpanie, Vitoria próbuje wskazać sposób ochrony praw im przysługujących. W przypadku niemożności korzystania z przynależnych praw Hiszpanie powinni „przemówić do rozsądku” Indianom, a dopiero wtedy, gdy Indianie zdecydują się na użycie siły, Hiszpanie mogą odpowiedzieć siłą, lecz tylko w samoobronie, co czyni zadość założeniom wojny sprawiedliwej (którą według Vitorii uzasadnia potrzeba obrony przed krzywdą bądź odpłata za krzywdę poniesioną). Wojna z Indianami musiałaby być ograniczona jednak tylko do wskazanej wyżej obrony przed krzywdą - stan Indian, którzy z natury są bojaźliwi i słabego umysłu, karze ograniczyć działania Hiszpanów tylko do obrony własnej (nie mogą korzystać z innych praw wojny, takich jak np. grabież majątku pokonanego). Co ciekawe, Vitoria nie wyklucza tego, by wojnę uznać za „obustronnie sprawiedliwą”, gdyż „po jednej stronie stoi prawo, po drugiej zaś niedająca się przezwyciężyć nieświadomość” ${ }^{27}$. Podbój krajów Indian dopuszczony jest według niego tylko wtedy, gdy wszelkie inne środki nie mogą zapewnić Hiszpanom bezpieczeństwa. Jeśli zaś i takie działania nie skruszą tubylców, to Hiszpanie, wykazawszy „,czynem i słowem” brak woli szkodzenia Indianom, mogą potraktować ich jako „zdradzieckich wrogów” i skorzystać z wszelkich praw wojny,

\footnotetext{
25 F. de Vitoria, De Indis, 3,3.

26 Ibidem, 3,4-5.

27 Ibidem, 3,6.
} 
w tym z prawa do obalenia ich władców - ze środków tych można wszak korzystać w wojnach między chrześcijanami, a „Indianie nie powinni być traktowani lepiej tylko dlatego, że są poganami”28.

Co więcej, nie tylko naturalne stosunki mogą uzasadnić przejście Indian pod władzę Hiszpanów, może to być również konsekwencja krzewienia religii chrześcijańskiej. Wynika to z tego, że chrześcijanie mają prawo krzewić swoją religię, ponadto papież może polecić Hiszpanom taką misję. Jeśli Indianie uniemożliwią prowadzenie ewangelizacji, to Hiszpanie mogą rozpocząć wojnę - i to nie tylko w celu zapewnienia bezpieczeństwa, które jest konieczne do głoszenia Ewangelii. Wydaje się, że osąd Vitorii jest wyważony, gdyż zauważa, że działania wojenne, łupiestwo i zabójstwa mogą raczej opóźnić, aniżeli przyspieszyć głoszenie Ewangelii:

Osobiście nie mam żadnych wątpliwości co do możności użycia przez Hiszpanów w razie potrzeby oręża i przemocy w celu przetrwania w tamtym kraju, obawiam się wszakże, aby nie przekroczyli granic zakreślonych przez prawo ludzkie i Boskie. [...] dobro [...] wynika zawsze z jednej i całkowitej przyczyny, zło natomiast pojawia się w miarę sprzyjających okoliczności ${ }^{29}$.

Działania Hiszpanów mogą znaleźć uzasadnienie nie tylko w naturze i krzewieniu wiary. Vitoria wskazuje jeszcze na kilka możliwych przyczyn związanych z ewentualnym konfliktem między nawróconymi Indianami a ich władcami trwającymi w bałwochwalstwie, istnieniem tyranii czy okrutnych praw, dobrowolnym wyborem, wewnętrznymi konfliktami, a wreszcie ukazuje kondycję Indian, którzy - niewiele różniąc się od ludzi pozbawionych rozumu - mogą wymagać opieki (Vitoria zakłada, że tego typu działanie musi mieć za cel wyłącznie dobro Indian).

\section{PODSUMOWANIE}

Kluczem dla zarysowanej wyżej koncepcji praw naturalnych Vitorii jest założenie, że wszyscy ludzie - czy to grzesznicy, czy niewierni, czy w końcu dzieci - posiadają pewne naturalne prawa. Pisząc, że tylko ludzie mogą posiadać prawa, Vitoria nie tylko odmawia tego innym bytom, tak ożywionym, jak i nieożywionym, lecz także zakorzenia je w naturze człowieka, a nie w świecie zewnętrznym. Jest to jeden z najbardziej doniosłych elementów doktryny Vitorii. Takie ujęcie będzie widoczne w wielu późniejszych koncepcjach. Na prace Vitorii w mniejszym stopniu oddziaływały prądy i literatura humanistyczna jego czasów aniżeli „starszy, teologiczny i filozoficzny humanizm”, który postrzegał człowieka jako zwieńczenie dzieła stworzenia (dla Vitorii wszystko, co zostało przez Boga stworzone, łącznie z najdalszymi gwiazdami, miało za ostateczny cel służbę człowie-

\footnotetext{
28 Ibidem, 3,7.

29 Ibidem, 3,13.
} 
kowi - „po cóż innego miałyby zostać uczynione?”30). Wydaje się, że właśnie ta część dorobku Vitorii ma największe znaczenie: stanowiąc istotną część prowadzonych w ramach Szkoły dyskusji nad uprawnieniami naturalnymi, pozwoliła koncepcjom średniowiecza powrócić w nowożytności jako użyteczne narzędzia.

Jednakże uzasadnienie działań podejmowanych przez Hiszpanów w Nowym Świecie wydaje się mniej przekonujące. I to nie dlatego, iż brak mu spójności (bo tak nie jest). Stanowi raczej wyraz naiwnej wiary w postawę Hiszpanów. Vitoria powtarza, że Hiszpanie mogą przybywać do Nowego Świata, gdy nie wyrządzają Indianom krzywdy ${ }^{31}$, natomiast Indianom nie przysługuje więcej praw niż chrześcijanom, ale też nie mniej, a jeden człowiek jest drugiemu człowiekiem, a nie - jak chce Owidiusz - wilkiem ${ }^{32}$, poza tym „Indianie są naszymi bliźnimi i mamy obowiązek troszczyć się o ich dobro"33.

Na tle innych myślicieli koncepcja Vitorii - myśliciela, który żywot spędził w bibliotekach i na salach wykładowych - wcale nie wydaje się wyjątkowo naiwna. Bartolomé de Las Casas, dopuszczając jedynie pokojowe nawrócenie Indian, widział w nich nie dzikusów czy też - jak chciał Vitoria - ludzi nie zawsze zdolnych do kierowania się rozumem, lecz delikatnych i cierpliwych, a nawet posuwał się do twierdzeń, iż w zdolności używania rozumu przewyższali oni starożytnych Greków i Rzymian ${ }^{34}$. Podobnie jak Vitoria Las Casas nigdy nie argumentował przeciwko obecności Hiszpanów w Nowym Świecie. Choć papież Aleksander VI przypisał Amerykę do ziem Korony Hiszpańskiej jako terytorium, na którym miała być prowadzona działalność misyjna (co dało hiszpańskim władcom możliwość żądania uniwersalnej jurysdykcji nad Indianami), to Las Casas wskazywał, że władztwo to musi być wykonywane nie tylko z poszanowaniem praw Indian, ale i za ich zgodą. W początkowej fazie podbojów dominikanin wierzył, iż Korona powstrzyma działania zdobywców. Zawiedziony pod koniec życia, argumentował, że władztwo Hiszpanii nie jest legalne - jedynie zwrot zagrabionych dóbr oraz uznanie praw Indian mogło ów stan zmienić. Jak łatwo zauważyć, Vitoria w sposób zbyt optymistyczny postrzegał rolę Hiszpanów, Las Casas zaś bezkrytycznie pisał o Indianach.

Podsumowując, można stwierdzić, że odkrycie Ameryki, będąc bodźcem dla odświeżenia poglądów na problematykę praw naturalnych wypracowanych w średniowieczu, wprowadziło w obszar zainteresowania idee, które odeszły w cień wraz z nadejściem Renesansu. Znaczenie takich myślicieli, jak Vitoria może być najlepiej dostrzeżone właśnie wtedy, gdy postrzegamy ich jako pomost

30 B. Tierney, The Idea of Natural Rights: Studies..., s. 272.

31 F. de Vitoria, De Indis, 3,1.

32 Ibidem, 3,3.

33 Ibidem, 3, 18.

${ }^{34}$ B. de Las Casas, Apologetic History of the Indies, www.columbia.edu/acis/ets/CCREAD/ lascasas.htm [dostęp: 27.02.2016]. 
pomiędzy scholastyką a nowożytnym ujmowaniem prawa, człowieka i świata. Dla zrozumienia znaczenia hiszpańskiej scholastyki istotne jest podkreślenie, iż Vitoria i inni myśliciele Szkoły wykorzystali idee uprawnień, aby rozwiązywać moralne problemy, z którymi musieli się zmierzyć ludzie ich epoki - posługiwali się ius, łącząc go z doktryną tomistyczną, dzięki czemu gdy później pojawiły się nowe wyzwania, termin ten był już szeroko znany wśród prawników i filozofów. W ich pracach odbiła się zarówno doktryna chrześcijańska, a w szczególności przekonanie, że człowiek został stworzony na obraz i podobieństwo Boga (stąd częste odnoszenie się i cytowanie Księgi Rodzaju), jak i tradycja filozoficzno-prawna, dzięki której mogli oprzeć idee uprawnień na wolnej woli i racjonalności jednostki ludzkiej.

\section{BIBLIOGRAFIA}

Araujo R.J., The Catholic Neo-Scholastic Contribution to Human Rights: The Natural Law Foundation, "Ave Maria Law Review" 2003, Vol. 159.

Brett A.S., Liberty, Right and Nature. Individual Rights in Later Scholastic Thought, New York 2003.

Henke L., Bartolomé de las Casas: An Interpretation of His Life and Writings, The Hague 1951.

Las Casas B. de, Apologetic History of the Indies, www.columbia.edu/acis/ets/CCREAD/lascasas. htm [dostęp: 27.02.2016].

Norena C.G., Studies in Spanish Renaissance Thought, The Hague 1975.

Stone M.W.F., The Nature and Significance of Law in Early Modern Scholasticism, [w:] A Treatise of Legal Philosophy and General Jurisprudence, Vol. 6: A History of the Philosophy of Law from the Ancient Greeks to the Scholastics, ed. F.D. Miller, Dordrecht 2007.

Tierney B., The Idea of Natural Rights - Origins and Persistence, "Northwestern Journal of International Human Rights" 2004, Vol. 2(1).

Tierney B., The Idea of Natural Rights: Studies on Natural Rights, Natural Law, and Church Law 1150-1625, Cambridge 2001.

Vitoria F. de, O Indianach, Warszawa 1954.

Vitoria F. de, On Civil Power, eds. A. Pagden, J. Lawrence, Cambridge 2012.

Vitoria F. de, On the American Indians (De Inidis), [w:] Vitoria: Political Writings, eds. A. Pagden, J. Lawrence, Cambridge 1991.

\section{SUMMARY}

The article presents the way in which Francisco de Vitoria justified the colonization of America. The considerations are based on the assumption that according to Vitoria, the relationship between the Spaniards and the inhabitants of the New World was based on the doctrine of natural powers. For this reason, the concept of the Spanish thinker should be taken considered. Its originality is based primarily on the fact that it used the idea of natural powers to solve current problems, and also let the concept known widely, but treated as an impractical legacy of the Middle Ages, became the basis for law and policy considerations. In this way he paved the way for modern ways of recognizing natural rights and, finally, human rights.

Keywords: natural rights; Spanish Scholasticism; Francisco de Vitoria 


\section{STRESZCZENIE}

W artykule przedstawiono sposób, w jaki Francisco de Vitoria uzasadniał kolonizację Ameryki. Rozważania podjęte w pracy opierają się na założeniu, że określenie relacji, w jakie mieli wchodzić Hiszpanie i mieszkańcy Nowego Świata, było według Vitorii oparte na doktrynie uprawnień naturalnych. $Z$ tego względu należy się uwaga koncepcji hiszpańskiego myśliciela. Jej oryginalność zasadza się przede wszystkim na tym, iż wykorzystał on ideę uprawnień naturalnych do rozwiązania bieżących problemów, a także pozwolił, by koncepcja powszechnie znana, lecz traktowana jako niepraktyczna spuścizna średniowiecza, stała się podstawą rozważań w zakresie prawa i polityki. Utorował w ten sposób drogę nowożytnym sposobom ujmowania uprawnień naturalnych i w końcu praw człowieka.

Słowa kluczowe: uprawnienia naturalne; scholastyka hiszpańska; Francisco de Vitoria 